УДК 658. 332

Битов В.П., к.е.н., доцент

Bitov V. Candidate of Economic Sciences, Associate Professor https://orcid.org 0000-0002-5828-0143

Горбач Л.М., к.е.н., доцент

Horbach L. Candidate of Economic Sciences, Associate Professor https://orcid.org 0000-0002-5977-6474

Котляров В.О., к.е.н., доцент

Kotliarov V. Candidate of Economic Sciences Associate Professor https://orcid.org 0000-0002-2291-3199

\title{
ІНВЕСТИЦІЙНА ДІЯЛЬНІСТЬ ЯК ЧИННИК ЕФЕКТИВНОГО РОЗВИТКУ СІЛЬСЬКОГОСПОДАРСЬКИХ ПІДПРИЕМСТВ
}

\author{
Міжрегіональна Академія Управління Персоналом, Украӥна
}

\begin{abstract}
У науковій статті розглянуто роль і значення надзвичайно важливого питання, а саме інвестування, яке $\epsilon$ сьогодні одним із визначальних на шляху розвитку економіки як на рівні підприємства, так i економіки держави. Адже саме в інвестиційному процесі об'єднується спільна діяльність багатьох учасників розвитку економічного зростання виробничих процесів, які працюють над розширенням основних фондів, що дають можливість збільшення виробництва продукції та забезпечення зростання прибутковості підприємства.

У статті відображено окремі посилання, що стосуються чинного законодавства, яким визначаються загальні, правові, економічні та соціальні умови інвестиційної діяльності для забезпечення рівного захисту прав, майна та інтересів із метою ефективного функціонування господарюючих суб'єктів у ринкових умовах.

Наведені також основні напрями інвестиційної стратегії, які передбачають планування та контроль за використанням капіталовкладень та вдосконалення їх технологічної структури, на користь досить вагомих в економіці галузей, що нами досліджуються i, зокрема, таких, що виробляють сільськогосподарську продукцію. Показано окремі позитивні приклади інвестиційної привабливості сільськогосподарських підприємств Волинської області.

Ключові слова: інвестииії, прибуток, капіталовкладення, ефективність, прибуток, основні фонди, ринкова економіка.
\end{abstract}

\section{INVESTMENT ACTIVITY AS A FACTOR OF EFFECTIVE DEVELOPMENT OF AGRICULTURAL ENTERPRISES}

\author{
Interregional Academy of Personnel Management, Ukraine
}

This publication examines the role and importance of an extremely important issue,namely investment, $\mathrm{w}$ hich today is one of the determinants of economic development both at the enterprise level and the state econom y.After all It is the investment process that unites the joint activities of many participants in the development of e conomic growth of production processes, workingto expand fixed assets, which allow to increase production and ensure the growth of profitability of the enterprise.

The article contains some references to current legislation, which defines the general,legal,economic and s ocial conditions investment activities to ensure equal protection of rights,property and interests in order to ensure the effective functioning of economic entities in market conditions.

The main directions of the investment strategy are presented in the article, which provide for planning and control over the use of investments and at the same time improvement of their technological structure, in favor of quite important in the economy industries that we study and in particular those that produce agriculturalproducts .Some positive examples of investment attractiveness of agroindustrial enterprises of Volyn region are shown.

Key words: investments, profit, investments, efficiency, profit, fixed assets, market economy.

Постановка проблеми у загальному вигляді та їі зв'язок 3 важливими науковими і практичними завданнями. Як свідчать наукові дослідження та практика господарської діяльності сьогодення, інвестиції є однією з основ розвитку підприємств, 
окремих галузей та економіки країни загалом. На сьогодні вимоги часу є такими, що вимагають від господарюючих підприємств i, особливо тих, що зайняті у сільськогосподарському виробництві застосування нових перспективних технологій, проведення сортозаміни сільськогосподарських культур, придбання високопродуктивних технічних засобів, а тому залучення інвестицій стане тим необхідним заходом, від якого залежатиме успіх чи занепад виробництва, а також рівень розвитку ресурсного та людського капіталів. Сьогодні наукові дослідження свідчать про те, що без надійних основ інвестиційної діяльності марно сподіватися на сталий розвиток виробництва, науково-технічний і соціальний прогрес, а отже, і на належне місце у світовому господарстві. На нашу думку, при цьому особлива увага повинна приділятися повноцінному аналізу щодо отриманих результатів від впроваджених інвестицій

Аналіз останніх досліджень і публікацій, у яких започатковано вирішення проблеми. Щодо аналізу останніх досліджень i публікацій iз питання залучення інвестицій у галузі сільського господарства i, зокрема, інвестиційної діяльності сільськогосподарських підприємств, то слід відзначити, що питання інвестицій та характеру їх участі в інвестуванні як реальних, які часто називають виробничими інвестиціями, або капітальними вкладеннями, а також фінансових, які забезпечують вагомий вплив на економічне зростання та успішний розвиток підприємств сьогодні привертає велику увагу як науковців, так і практиків. Адже, як відомо, інвестиційний процес прискорює темпи відтворення засобів виробництва, а також дає можливість впровадженню перспективних інноваційних технологій. Виходячи з цього та вивчаючи приклади інвестування сільськогосподарських підприємств, приходимо до висновку, що чим активніший інвестиційний процес, тим стрімкіші темпи відтворення засобів виробництва i робочої сили. Питання теорії i практики інвестицій та інвестиційної стратегії підприємств вивчалися багатьма зарубіжними та вітчизняними вченими i, зокрема, такими як: М. Бромвич, Д. Гарнер, Л. Гітман, М. Джонк, С. Майерс, П. Хавранек, Б. В. Губський, О.Д. Гудзінський, С. О. Гуткевич, А. О. Заїнчковський, М. І. Кісіль, І. І. Лукінов, Б. Й. Пасхавер, А. А. Пересада, О. М. Пєтухова, Г. М. Підлісецький, С. І. Прилипко, П. С. Рогожин, В.П. Савчук, В. Г. Федоренко, В. Я. Шевчук та інші.

Проте, на нашу думку, питання щодо інвестиційної діяльності сільськогосподарських підприємств потребує подальшого дослідження та вивчення i, зокрема, ролі та значимості результатів від залучених інвестицій, що і зумовило вибір теми публікації.

Цілі статті. Метою статті $є$ розкриття сутності як теоретичних висновків, так і практики залучення інвестицій сільськогосподарськими підприємствами. В статті окреслено роль і значимість інвестування i, зокрема, на прикладах агропромислових підприємств різних форм власності Волинської області. Відображено важливість інвестування у забезпеченні ефективних результатів у сучасному сільськогосподарському підприємстві та розв'язанні соціальних і економічних проблем суспільства в умовах ринку.

Виклад основного матеріалу дослідження 3 повним обгрунтуванням отриманих наукових результатів. Тема публікації щодо інвестиційної діяльності, як чинника до ефективного розвитку підприємств сільськогосподарської галузі, та відповідні практичні методи здійснення інвестування, як способу впливу в досягненні цілей підприємства, обрана нами 3 метою показати, що саме сьогодні залучення інвестицій $\epsilon$ особливо важливим для забезпечення відповідних результатів господарської діяльності підприємств. У статті за мету поставлено висвітлити як наукові погляди 3 приводу інвестування сільськогосподарських підприємств, так і практичне 
відображення окремих прикладів роботи в даному напрямку, зокрема, в сільськогосподарській галузі Волинської області.

У Волинській області, як і в Україні сільське господарство є надзвичайно важливим структурним елементом агропромислового комплексу країни, від ефективного розвитку якого значною мірою залежить сталий розвиток економіки країни загалом. На сьогодні

на території області під сільськогосподарськими угіддями зайнято 1047,5 тис. га, що становить $52 \%$ площі регіону [11, с. 21].

Зміна форм власності на землю й основний та оборотний капітал, інші трансформаційні процеси обумовили певну зміну соціально-економічної сутності й значення сільськогосподарського виробництва у його розвитку. Нині відстежується виняткова роль аграрного сектора i, зокрема, сільськогосподарських підприємств у розвитку економіки країни, а тому вона потребує досконалої структурної перебудови сільськогосподарського виробництва на інноваційних засадах; забезпечення продовольчої безпеки; покращення інвестиційної привабливості галузі; вдосконалення функціонування об'єктів ринкової та інноваційної інфраструктури; розвитку сільськогосподарської обслуговуючої кооперації та агропромислової інтеграції; диверсифікованої структури сільської економіки, орієнтованої на ефективне використання місцевих ресурсів; активізації підприємницької діяльності; дотримання європейських та світових стандартів якості і безпеки харчування тощо [4, с. 56-60]. Задля повного вирішення цих завдань, практичний досвід показує необхідність залучення інвестицій. На переконання науковців і практиків, у даний час інвестиції є основою розвитку підприємств та економіки країни. Від уміння успішного інвестування залежить не тільки успіх чи занепад власного виробництва, а можливості вирішення соціальних та екологічних проблем, сучасний рівень і потенційний динамізм фізичного, фінансового та людського капіталів [6, с. 52].

Щодо інвестиційної привабливості Волині в цілому, то ії обумовлює вигідне географічне розташування, потужний ресурсний та кадровий потенціал, а також, що $є$ досить важливим - це динамічний розвиток економіки та інноваційноорієнтовані багатопрофільні сільськогосподарські виробництва. Щодо напрямів інвестиційної стратегії, то відзначимо, що така стратегія спирається на визначення плану розвитку аграрного сектору України та сільських територій i побудована на чинних нормативно-правових документах, зокрема Стратегії сталого розвитку «Україна - 2020», яка визначає довгострокову концепцію розвитку сільського господарства і сільських територій, надає базу для стабільної, передбачуваної і прозорої правової системи, спрямованої на покращення ділового клімату, протидію корупції і стимулювання інвестицій для модернізації сільськогосподарського сектору. Вона також надає підгрунтя для проведення інституціональної реформи, необхідної для ефективного контролю i реалізації, a також зростання конкурентоспроможності продукції сільськогосподарської галузі, намагаючись водночас забезпечити дієвість у сприянні розвитку сільських територій і покращенні якості життя та збереженні природних ресурсів та довкілля.

На сучасному етапі розвитку економіка України, включаючи іiі агропромисловий комплекс, перебуває у стані, що вимагає значного покращення. Адже, як відомо, негативний вплив мають структурні, міжгалузеві диспропорції, що накопичилися у національному господарстві впродовж кількох десятиліть й призвели до гострого дефіциту товарів виробничого й невиробничого призначення i, особливо, енергоносіїв. Негативні наслідки посилюється також розбалансованістю фінансово-кредитної системи, невідповідністю сформованих управлінських структур потребам економічного розвитку $[9$, с. $45-50]$. 
Для наочного прикладу покажемо в аналітичній таблиці окремі показники результатів роботи сільськогосподарської галузі за 2014-2019 роки.

Таблиця 1

Показники галузі АПК за 2014-2019 роки*

\begin{tabular}{|l|c|c|c|c|c|c|}
\hline & 2014 & 2015 & 2016 & 2017 & 2018 & 2019 \\
\hline $\begin{array}{l}\text { Валовий регіональний продукт } \\
\text { Частка у } \\
\text { загальнообласному показнику, \%) }\end{array}$ & 27,9 & 20,3 & 18,3 & 15,4 & 13,6 & 14,0 \\
\hline $\begin{array}{l}\text { Продукція сільського } \\
\text { господарства } \\
\text { Усі категорії (млн. грн.) }\end{array}$ & 6744,10 & 6434,40 & 6558,50 & 6872,10 & 7089,20 & 7101,30 \\
\hline Продукція рослинництва & 3806,30 & 3657,60 & 3785,80 & 4121,60 & 4405,70 & 4479,00 \\
\hline Продукція тваринництва & 2937,80 & 2776,80 & 2772,70 & 2750,50 & 2683,50 & 2622,30 \\
\hline $\begin{array}{l}\text { Продукція сільського } \\
\text { господарства } \\
\text { Сільськогосподарські } \\
\text { підприємства (млн. грн.) }\end{array}$ & 2404,80 & 2375,10 & 2572,20 & 2853,00 & 3160,30 & 3234,10 \\
\hline Продукція рослинництва & 1289,70 & 1219,30 & 1363,80 & 1635,80 & 1926,30 & 1968,50 \\
\hline Продукція тваринництва & 1115,10 & 1155,80 & 1208,40 & 1217,20 & 1234,00 & 1265,60 \\
\hline $\begin{array}{l}\text { Продукція сільського } \\
\text { господарства Господарства } \\
\text { населення (млн. грн.) }\end{array}$ & 4339,30 & 4059,30 & 3986,30 & 4019,10 & 3927,70 & 3867,20 \\
\hline Продукція рослинництва & 2516,60 & 2438,30 & 2422,00 & 2485,80 & 2470,00 & 2510,50 \\
\hline Продукція тваринництва & 1822,70 & 1621,00 & 1564,30 & 1533,30 & 1457,70 & 1356,70 \\
\hline
\end{tabular}

* Складено авторами на підставі даних Головного управління статистики у Волинській області.

Показники, наведені в таблиці, свідчать про окремі позитивні результати роботи, так і про відставання від рівня 2014 року. Проведений аналіз показників, наведених у таблиці, спонукає до пошуку шляхів покращення результатів господарської діяльності. Досліджуючи дане питання, приходимо до висновку, що поряд зі всіма існуючими методами впливу на покращення результатів діяльності підприємств сільськогосподарського виробництва, є необхідність у залученні інвестицій.

Як свідчить практичний досвід, інвестиції є основою розвитку підприємств, окремих галузей та економіки країни загалом. Разом із тим, проведені дослідження вказують, що стан інвестиційної діяльності в аграрному секторі економіки України знаходиться ще на недостатньому, а то й низькому рівні. Що стосується вивчення досвіду інвестиційної привабливості агропромислових підприємств Волинської області, то тут позитивний вплив на інвестиційну привабливість та формування інноваційного потенціалу має значна частка великих товарних аграрних підприємств та ефективних фермерських господарств, які відзначаються вищим рівнем мобільності та адаптованості до інновацій. Беручи до уваги наближеність Володимир-Волинського, Іваничівського, та Любомльського районів до кордону з СС, а також наявність значного потенціалу для розвитку високоспеціалізованого сільського господарства (екологічно-чистого землеробства, органічного тваринництва, переробки молока i сироваріння на інноваційній основі тощо) дає підстави для залучення інвестицій у реалізацію різних інвестиційних проектів.

Для повнішої інформації наведемо показники статистичної звітності соціальноекономічного розвитку сільськогосподарської галузі Волині за I півріччя 2020 року, де відображено кількість сільськогосподарських формувань, поголів'я сільськогосподарських тварин, а також виробництво і реалізацію продукції, вкладення інвестицій та фінансово-економічні результати. 
У січні-червні 2020 року індекс сільськогосподарської продукції порівняно із відповідним періодом 2019 року становив 97,3 \%, у тому числі в агропідприємств $100,8 \%$, у господарств населення $-93,8 \%$.

За даний період вироблено сільськогосподарської продукції на суму понад 2,6 млрд грн. Питома вага області у виробництві продукції сільського господарства в державі за січень-червень 2020 року становила 3,3 \%, за обсягами виробництва продукції сільського господарства область посідає 14 місце, за темпами виробництва - 9 місце, за обсягами виробництва на 1 жителя - 7 місце в державі. Обсяг виробництва продукції сільського господарства в розрахунку на 1 особу складає 2557 гривень.

Виробництвом сільськогосподарської продукції займаються близько 1000 агропідприємств, із них - 640 фермерських господарств, а також близько 150 тисяч особистих селянських господарств.

Слід відзначити, що внаслідок наявності кормової бази (вирощування зернофуражних культур, картоплі тощо), а також соціально-економічних чинників (концентрації населення, наявністю ринків збуту продукції тощо), галузі тваринництва у центральних та південних районах Волинської області також розвинуті краще, ніж у північних районах. Так, найбільше поголів'я великої рогатої худоби станом на 2018 p налічується на підприємствах Луцького, Горохівського та Турійського районах, свиней - у Володимир-Волинському, Ковельському та Рожищенському районах.

В усіх категоріях господарств станом на 1 липня 2020 року утримується: 130,1 тисячі голів ВРХ (питома вага господарств населення - 68 \%); у т.ч. 80,3 тисячі корів (питома вага господарств населення - 78 \%); 251,3 тисячі свиней (питома вага господарств населення - $72 \%)$.

Усіма категоріями господарств за січень-червень 2020 року вироблено 79,2 тисяч тонн м'яса в живій вазі (32 \% - продукція господарств населення), 182,8 тисячі тонн молока (73\% - продукція господарств населення).

Хоча в області зберігається тенденція до зменшення кількості корів, у сільськогосподарських підприємствах виробництво молока у червні 2020 року збільшено на 5,6 \% і дорівнює 49,4 тисячі тонн, що вказує на збільшення продуктивності корів в аграрних підприємствах області.

Слід відзначити, що у Волинській області рослинництво переважає над тваринництвом у співвідношенні 62,1 \% до 37,9 \% загального обсягу продукції, а у структурі сільськогосподарських угідь найбільші площі зайняті під ріллею. Явище зумовлене сприятливими природними умовами для вирощування сільськогосподарських культур: рівнинністю рельєфу, достатньою зволоженістю території тощо. Так, найбільшу площу посівів на території Волинської області займають зернові та зернобобові культури, зокрема, пшениця, жито, ячмінь, овес тощо. Окрім того, вирощують технічні культури (соя, ріпак, кольза), цукрові буряки, картоплю та овочі. Зауважимо, що садівництво у Волинській області розвинуто мало, що зумовлено особливостями природних умов території. Вирощують переважно культури, які не потребують великої кількості тепла та родючих грунтів (малина, полуниця, лохина, яблука та ін.). Загалом багаторічні насадження займають невеликі території - 11,7 тис. га, що становить 1,1% від площі всіх сільськогосподарських угідь. Оскільки в області добре розвинуто тваринництво, а у його структурі основними галузями виступають скотарство, свинарство, птахівництво та вівчарство [11, с. 86], то сіножаті та пасовища займають 15,4 \% та 19,3 \% площі сільськогосподарських угідь відповідно.

В поточному році, згідно оперативних даних, до збирання підлягає 421,0 тис. га сільськогосподарських культур, із них 302,0 тис. га зернових культур, 38,0 тис. га сої, 31,0 тис. га соняшника, 50,5 тис. га ріпаку. Ранні зернові культури в цьому році займають площу 269,0 тис. га, у тому числі озимий ячмінь - 6,9 тис. га, пшениця $-171,1$ тис. га, озиме жито - 22 тис. га, ярий ячмінь $-29,0$ тис. га, овес $-35,0$ тис. га, горох $-5,0$ тис. га. Крім того, кукурудза на зерно 30 тис. га, гречка $-2,0$ тис. га, просо - 1,0 тис. га. 
В цьогорічних жнивах буде залучено 3057 зернозбиральних комбайнів, у тому числі 537 одиниць - у сільськогосподарських підприємствах і 2520 одиниць - у господарствах населення. Розрахункове середнє навантаження на зернозбиральний комбайн складає 99 га, у тому числі в сільськогосподарських підприємствах - 256 га, в господарствах населення - 65 га.

За січень-травень 2020 року реалізовано продукції виробництва харчових продуктів, напоїв (у відпускних цінах без ПДВ і акцизу) на суму 3 млрд. грн., що складає 26,8 \% у загальному обсязі реалізованої промислової продукції регіону.

Інвестиційна діяльність при цьому визнана однією із пріоритетних для розвитку сільських територій області. У 2019 р. підприємствами, що займалися сільським господарством, мисливством та пов'язаними з ними послугами, вкладено 1 307,6 млн грн капітальних інвестицій, що становило 10,4 \% загальнообласного обсягу, у I кварталі 2020 року - 126,3 млн. грн., або $8 \%$.

Висновки. У статті авторами розкрито сутність як теоретичних висновків, так i практики залучення інвестицій сільськогосподарськими підприємствами. В дослідженні показано окремі показники результатів роботи агропромислового комплексу сільськогосподарських підприємств i значимість інвестування на прикладах агропромислових підприємств Волинської області. Відображено важливість інвестування у забезпеченні ефективних результатів у сучасному сільськогосподарському підприємстві та розв'язанні соціальних і економічних проблем суспільства в умовах ринку. Наведені приклади залучення інвестицій та інвестиційної привабливості сільськогосподарських підприємств різних форм власності.

\section{Список бібліографічного опису}

1.Загальна економіка: Підручник / За ред. І. Ф. Радіонової. - К.-Подільський, 2002. - С. $200-218$.

2.Про інвестиційну діяльність: Закон України від 18 вересня 1991 р. // Відомості Верховної Ради України. - 1991. - № 47. - ст. 646

3.Про захист іноземних інвестицій в Україні: Закон України // Відомості Верховної Ради України. - 1991. - № 46. 4. Титаренко Н. О. Теорії інвестицій: Навч. посібн. - К.: КНЕУ, 2000. - 160 с.

5.Гальчинський А., Льовочкін С. Становлення інвестиційної моделі економічного зростання України // Економіка України. - 2004. - № 6. - С. 4-11.

6.Данілов О.Д., Івашина Г.М., Чумаченко О.Г. Інвестування: Навч. посібн. - К.: Видавничий дім «Комп’ютер-прес», 2001. -364 c.

7.Козаченко Г. В., Антіпов О. М., Ляшенко О. М., Дібніс Г. І. Управління інвестиціями на підприємстві. - К.: Лібра, 2004. -368 c.

8.Майорова Т. В. Інвестиційна діяльність: Навч. посібн. - К.: Центр навчальної літератури, 2004. - 376 с.

9.Пересада А. А. Управління інвестиційним процесом. - К.: Лібра, 2002. - 472 с.

10. Мадзігон В. В. Теорія попиту і пропозиції в підприємницькій діяльності в реаліях ринкової економіки на товари і послуги // Молодь і ринок. - 2011. - № 2(73). - С. 41-46.

11. Екологічний паспорт Волинської області. - Луцьк, 2020. - 154 с. [Електронний ресурс]. - Режим доступу: https://voladm.gov.ua/article/ekologichniy-pasport-volinskoyi-oblasti-za-2019-rik/

\section{References}

1. .General Economics: Textbook / Ed. IF Radionova - K. - Podolsky, 2002. P.200-218.

2. Law of Ukraine "On Investment Activity" of September 18, 1991.

3. Law of Ukraine "On protection of foreign investments in Ukraine" // Bulletin of the Verkhovna Rada. - 1991. - №46.

4.. Tytarenko NO, Investment Theories: Textbook. manual. - K .: KHEУ, 2000. - 160c.

5. Galchinsky A., Levochkin S. Formation of the investment model of economic growth of Ukraine // Economy of Ukraine. 2004. - №6. - P. 4-11.

6. Danilov OD, Ivashina GM, Chumachenko OG Investing: Textbook. pos. - Kyiv: Computerpress Publishing House, 2001. $364 \mathrm{p}$.

7. Kozachenko GV, Antipov OM, Lyashenko OM, Dibnis GI Enterprise investment management. - K. Libra, 2004. - 368 p.

8.Mayorova TV Investment activity: Textbook. pos. - Kyiv: Center for Educational Literature, 2004. - 376 p.

9.Presada AA Investment process management. - К .: Лiбpa, 2002. - 472 c. 8

10.Madzigon VV Theory of supply and demand in business in the realities of a market economy for goods and services // Youth and the market. - 2011. - № 2 (73). - P. 41-46.

11. Ecological passport of Volyn region. - Lutsk, 2020. - 154 p. [Electronic resource]. - Access mode: https://voladm.gov.ua/article/ekologichniy-pasport-volinskoyi-oblasti-za-2019-rik/

Дата подання публікації 03.09.2020 p. 